\title{
A Postharvest Fruit Rot in d'Anjou Pears Caused by Sphaeropsis pyriputrescens sp. nov.
}

\author{
C. L. Xiao, Department of Plant Pathology, Washington State University, Tree Fruit Research and Extension Center, \\ 1100 N. Western Avenue, Wenatchee 98801; and J. D. Rogers, Department of Plant Pathology, Washington State \\ University, Pullman 99164-6430
}

\begin{abstract}
Xiao, C. L., and Rogers, J. D. 2004. A postharvest fruit rot in d'Anjou pears caused by Sphaeropsis pyriputrescens sp. nov. Plant Dis. 88:114-118.

During a survey of postharvest diseases in stored pears conducted in the 2001-02 storage season, a new postharvest fruit rot in d'Anjou pears was discovered in Washington State. Symptoms of this disease were stem-end rot, calyx-end rot, and wound-associated rot, which presumably originated from infections of stem, calyx, and wounds on the fruit surfaces, respectively. The decayed area on the fruit was firm or spongy and appeared brown. During the late storage period from March to May 2002, this disease was observed in 19 of 39 lots and accounted for 2 to $21 \%$ of all decayed fruit. The causal agent, Sphaeropsis sp., was consistently recovered from decayed fruit with the symptoms described above. Two isolates of the fungus were used for pathogenicity tests on pear fruit. Decay symptoms developed on fruit inoculated with spore suspensions of the fungus on the stem, calyx, and wounds on the fruit surface. The fungus was reisolated from these decayed fruit. The fungus, Sphaeropsis pyriputrescens sp. nov., was characterized and described. On potato dextrose agar (PDA), oatmeal agar, and pear juice agar at $20^{\circ} \mathrm{C}$, the fungus grew at mean rates of 21,15 , and $24 \mathrm{~mm} \mathrm{day}^{-1}$ in colony diameter, respectively. On PDA, the fungus formed a circular colony with dense, hyaline hyphae and a few or some aerial mycelia. Colonies appeared light yellow to yellow on 2-week-old PDA cultures. The fungus grew at temperatures from 0 to $25^{\circ} \mathrm{C}$, with optimum growth between 15 and $20^{\circ} \mathrm{C}$, little or no growth at $30^{\circ} \mathrm{C}$, and no growth at $35^{\circ} \mathrm{C}$. This is a low-temperature species.
\end{abstract}

Additional keywords: postharvest decay, Pyrus communis

In the United States, winter pears are produced primarily in the Pacific Northwest. d'Anjou (Pyrus communis L.) is the major winter pear cultivar grown in the region. Postharvest fruit rot is a limiting factor for the long-term storage of winter pears. In general, there are two groups of postharvest diseases in pome fruits: those that originate from incipient or quiescent infections of fruit by fungi in the orchard and those that originate from infections of wounds, such as stem punctures and bruises, by fungi after harvest or during the handling and packing process (9). The latter category is exemplified by blue mold rot caused by Penicillium spp., primarily $P$. expansum Link, gray mold rot caused by Botrytis cinerea Pers., and Mucor rot caused by Mucor piriformis E. Fischer. Postharvest fruit rots in pears, particularly

Corresponding author: C. L. Xiao

E-mail: clxiao@wsu.edu

Accepted for publication 16 September 2003.

Publication no. D-2003-1120-01R

(C) 2004 The American Phytopathological Society those caused primarily by wound pathogens, are largely affected by postharvest handling practices.

In Washington State, d'Anjou pears are harvested in mid-September. Packing begins shortly after harvest and may last until early January. During packing, fruit with noticeable wounds or other damage are removed from the packing line. Visually sound pears are individually wrapped in paper and packed into cardboard boxes ( 20 $\mathrm{kg}$ per box), and then stored in controlled atmospheres ( 1 to $2 \% \mathrm{O}_{2}$ and $0.5 \% \mathrm{CO}_{2}$ ) at -1 to $0^{\circ} \mathrm{C}(6)$. Fruit can be stored for up to 9 months. Severe fruit rot may develop on fruit that are stored in cardboard boxes after a period of time in storage. Under the current Washington State standard, only $2 \%$ decay is allowed in a $20-\mathrm{kg}$ pear box. Repacking is often required in order to meet the standard. Stem-end and calyx-end rots are the common decay problems in packed d'Anjou fruit stored in cardboard boxes (C. L. Xiao, unpublished data). During a survey of postharvest diseases in stored pears conducted in the 2001-02 season, an undescribed species of Sphaeropsis was consistently recovered from decayed pears with symptoms of stem-end rot, calyx-end rot, or rot associated with wounds on the fruit surfaces from some lots (orchards). In this paper, we describe, for the first time, this new postharvest disease in pears and the causal agent, a new species of Sphaeropsis.

\section{MATERIALS AND METHODS}

Symptoms, prevalence, and incidence of the disease in storage. A survey of postharvest diseases of d'Anjou pears was conducted in north central Washington State, the primary production area of d'Anjou pears in the state. Decayed pear fruit were sampled from four commercial packinghouses during fruit packing from November 2001 to January 2002 (early storage before packing, i.e., pears are stored in field bins) and during repacking (removing decayed fruit and transferring marketable fruit into new containers) or repackaging (transferring fruit into different-size containers as requested by buyers) from March to May 2002 (late storage, i.e., pears are stored in cardboard boxes after packing). Approximately 60 decayed fruit were sampled from each lot. Decayed fruit were sorted by infection sites (stem end, calyx end, or fruit skin) and presence of wounds. Color of decayed areas and type of decay (soft or watery decay versus firm or spongy decay) also were recorded. Decayed fruit were photographed before isolation in order to match causal agents with the disease symptoms they incited.

Isolation of the causal agent. When sporulation or fruiting bodies of decay pathogens were present on decayed fruit, identification of causal agents was made based on the signs of pathogens or morphology of fungi under the microscope. If no positive signs of pathogens on decayed fruit were present, isolations from decayed fruit were made to determine causal agents. Decayed fruit were lightly sprayed with $70 \%$ ethanol and air-dried in a laminar flow hood. Fragments (approximately $5 \times 5 \times 3 \mathrm{~mm}^{3}$ ) of decayed fruit were removed with a sterile scalpel from the margins of decayed and healthy tissues and placed on acidified potato dextrose agar (APDA) $(4.0 \mathrm{ml}$ of a $25 \%$ solution of lactic acid per liter of medium). Plates were incubated at room temperature $\left(20\right.$ to $22^{\circ} \mathrm{C}$ ) 
for 3 to 14 days and examined for culture development. Fungi that grew on or in the APDA were transferred onto fresh APDA. Pure cultures were then transferred onto PDA. Mycelium plugs of these cultures were stored either in sterile water at $4^{\circ} \mathrm{C}$ or in $15 \%$ glycerol at $-80^{\circ} \mathrm{C}$.

Pathogenicity tests. Two isolates of Sphaeropsis sp. (CLX-1022 and CLX1026) collected from decayed pear fruit during the 2001-02 storage season were used in the pathogenicity tests. Fruit of d'Anjou pear that had been harvested from a commercial orchard without postharvest fungicide treatments were used for the experiment. Fruit were surface-disinfested for $5 \mathrm{~min}$ in $0.5 \% \mathrm{NaOCl}$, rinsed three times with sterile distilled water, and then air-dried. Fruit were wounded with a sterile 4-mm-diameter nail head to a depth of $4 \mathrm{~mm}$, and a 4-mm-diameter mycelium plug from a 4-day-old PDA culture was cut and placed in the wound of each fruit. The inoculation site was covered with a piece of sterile moist cheesecloth $\left(2 \times 2 \mathrm{~cm}^{2}\right)$, and inoculated fruit were then gently wrapped with sterile aluminum foil. Inoculated fruit were either placed on fiberboard pear trays wrapped in perforated polyethylene bags and stored in cardboard boxes in air at $0^{\circ} \mathrm{C}$ or kept in aluminum muffin trays in a sealed plastic container with a shallow depth (about $1 \mathrm{~mm}$ ) of water on the bottom at room temperature (20 to $22^{\circ} \mathrm{C}$ ). Ten replicate pear fruit were inoculated with each isolate of the fungus for each temperature. Fruit rot development was evaluated 1 week (room temperature) and 2 weeks $\left(0^{\circ} \mathrm{C}\right)$ after inoculation. Isolations of fungi were made from the decayed fruit as previously described to confirm Koch's postulates. The experiment was conducted twice.

A separate experiment was also conducted during the 2002-03 storage season. Fruit were prepared in the same manner as above. Pycnidia of isolate CLX-1026 produced on 4-week-old cultures on oatmeal agar (OMA, $60 \mathrm{~g}$ of iron- and zincfortified single-grain oatmeal [Gerber, Fremont, MI] with $15 \mathrm{~g}$ of agar in 1,000 $\mathrm{ml}$ of deionized water, sterilized for 90 min) incubated at $20^{\circ} \mathrm{C}$ under 12 -h alternating cycles of dark and fluorescent light were used to make the conidial suspensions. Pycnidia were collected by scraping them off the surfaces of cultures with a sterile scalpel and gently crushed with a pestle in a mortar. Approximately $25 \mathrm{ml}$ of sterile water was added to the mortar to make conidial suspensions, which were then filtered through four layers of cheesecloth.

Concentrations of the spore suspensions were adjusted to $1 \times 10^{4}$ conidia per $\mathrm{ml}$. Pieces of sterile cheesecloth $(2 \times 2 \mathrm{~cm})$ were dipped into the spore suspension. Prior to inoculation, the end of the stem of each fruit was slightly cut horizontally with a sterile scalpel to make a wound. The end of the stem, calyx, and a fresh wound on the fruit surface made with a nail head as previously described were inoculated by covering them with a piece of wet cheesecloth containing the spore suspension of the fungus. For a control treatment, fruit were wounded as described above and treated with cheesecloth moistened with sterile water. There were three replicates of nine fruit each per treatment. Inoculated fruit were kept in plastic containers with a shallow depth of water (about $1 \mathrm{~cm}$ ) on the bottom at room temperature $\left(20\right.$ to $22^{\circ} \mathrm{C}$ ) overnight. Cheesecloth was removed and fruit were placed on fiberboard pear trays wrapped in perforated polyethylene bags and stored in cardboard boxes in air at $0^{\circ} \mathrm{C}$. Fruit were monitored for decay development monthly. Ten decayed fruit, inoculated at the stem, calyx, or on the fruit surface were arbitrarily selected for reisolation of the fungus from diseased tissues as previously described. The experiment was conducted twice.

Identification and characterization of the fungus. Morphological characteristics of the fungus in pure culture and fruiting bodies (pycnidia) produced on decayed pear fruit from storage were studied. Conidia and conidiophores were examined by differential interference contrast microscopy of water mounts and dark field fluorescence microscopy of mounts in Calcofluor White PMW (American Cyanamid Co., Parsippany, NJ) (0.1 g per $50 \mathrm{ml}$ of $\mathrm{H}_{2} \mathrm{O}$ ). Herbarium specimens were obtained from USDA ARS Systematic Botany and Mycology Laboratory in Beltsville, MD, and the Farlow Herbarium at Harvard. Herbarium designations follow Holmgren et al. (4).

Three isolates of Sphaeropsis sp. recovered from decayed pear fruit were used in the cultural studies. One isolate of Sphaeropsis malorum recovered from apple fruit in Washington State, provided by Rodney Roberts (USDA ARS, Wenatchee, WA), was also included for comparison with isolates of Sphaeropsis sp. Colony morphology was evaluated on PDA, OMA, and pear juice agar (PJA). PJA was prepared by mixing $200 \mathrm{ml}$ of freshly made pear juice with $15 \mathrm{~g}$ of agar and $3 \mathrm{~g}$ of $\mathrm{CaCO}_{3}$ in $800 \mathrm{ml}$ of deionized water and sterilizing for $20 \mathrm{~min}$. Development of pycnidia of the fungus on OMA incubated at $20^{\circ} \mathrm{C}$ under 12 -h fluorescent light/12-h dark was also monitored. To determine mycelial growth of the fungus at different temperatures, 4-mm mycelial plugs were removed with a sterile cork borer from the leading edges of 4-day-old PDA cultures, and then transferred onto OMA in 90-mmdiameter petri plates. The cultures were incubated at $0,5,10,15,20,25,30$, and $35^{\circ} \mathrm{C}$. There were three replicate plates for each isolate at each temperature. Colony diameters of each plate were measured after 1,2 , and 3 days of incubation. Be- cause both fungi grow slowly at 0 and $5^{\circ} \mathrm{C}$, colony diameters were also measured at 10 and 30 days after inoculation. Cultures that did not grow after 10 days at 30 or $35^{\circ} \mathrm{C}$ were transferred to $20^{\circ} \mathrm{C}$. Colony diameters were measured after 4 days to determine whether the fungus resumed growth. The daily mycelial growth rate was calculated. The experiment was conducted twice.

\section{RESULTS}

Symptoms and isolation of causal agent. Symptoms on decayed fruit from which the newly isolated fungus was recovered were stem-end rot, calyx-end rot, and wound-associated rot, which originated from infections of stem, calyx, and wounds on the fruit surfaces, respectively (Fig. 1). The decayed tissue was firm or spongy. The decayed areas appeared brown. As the disease advanced, the fungus might form pycnidia in the decayed areas, usually starting from infection sites (Fig. 1B and E). The pycnidia were black, superficial or partially embedded in the decayed tissue (Fig. 1G and H). The skin of decayed areas generally remained brown or dark brown but sometimes appeared dark in aged decayed areas. Under high humidity conditions, the entire fruit were frequently covered by mycelia and pycnidia of the fungus. The internal decayed flesh appeared brown. Decay in the fruit flesh developed along the vascular tissue, originating from infection of the stem or calyx (Fig. 1C and F).

An undescribed fungus was consistently isolated from decayed pears with the symptoms described above. Isolations from decayed tissues yielded the same fungus and one colony type on APDA. The colonies first appeared with dense hyaline mycelium that later turned light yellow to yellow. Black pycnidia of the fungus sometimes formed on 4- to 5-week-old cultures in isolation plates.

Prevalence and incidence of the disease. During pear packing from November 2001 to January 2002, decayed pear fruit were sampled from 33 different lots (orchards). This new disease, caused by the undescribed fungus, occurred on fruit from 14 of 33 orchards and accounted for $4 \%$ of the decayed fruit, which ranged from 2 to $8 \%$. During the late storage from March to May 2002, decayed pear fruit were sampled from 39 different lots. This disease occurred in 19 of 39 lots and accounted for $6 \%$ of the decayed fruit, which ranged from 2 to $21 \%$.

Pathogenicity tests. All pears that were wounded and inoculated with mycelium plugs of the fungus developed decay symptoms at 20 and $0^{\circ} \mathrm{C}$ as described above. The original fungus was reisolated from decayed fruit. No decay developed on fruit in the control treatment. In separate experiments conducted during the 2002-03 storage season, where the stem 
and calyx of pear fruit were inoculated with spore suspensions of the fungus, it took 2 to 4 months at $0^{\circ} \mathrm{C}$ for the fungus to move through stem tissue to reach flesh of the fruit and cause decay. Four months after inoculation, $91 \%$ of stem-inoculated fruit and $63 \%$ of calyx-inoculated fruit developed fruit rot. All skin woundinoculated fruit developed fruit rot 4 to 6 weeks after inoculation. No decay developed on fruit in the control treatments.
The original fungus was reisolated from decayed fruit.

The fungus. Sphaeropsis pyriputrescens Xiao \& J.D. Rogers, sp. nov. Fig. $1 \mathrm{G}$ and H; Fig. 2A and B.

Etymology: pyri $=$ pear + putrescens $=$ rotting

Pycnidia parte immersa vel fere superficiaria, subglobosa vel plus minusve ad apicem complanata, separata vel aggregata in numera parva, 0.3-0.7 $\mathrm{mm}$ diam, cum pariete incrassato praedita. Ostiola cum poro inconspicuo praedita. Cellulae conidiogenae subglobosae, 12-16 $\mu \mathrm{m}$ longae, 8-12 $\mu \mathrm{m}$ latae, parieti pycnidii affixae, fortasse in modo percurrente extensae; conidia efferentia in modo holoblastici. Conidia brunnea, clavata vel subglobosa vel irregularia in extremo dehiscentiae complanata, levia, (11-)14-17(-23) × (7-)810(-13) $\mu \mathrm{m}$. (Ave. $25=16 \times 10 \mu \mathrm{m}$ ).
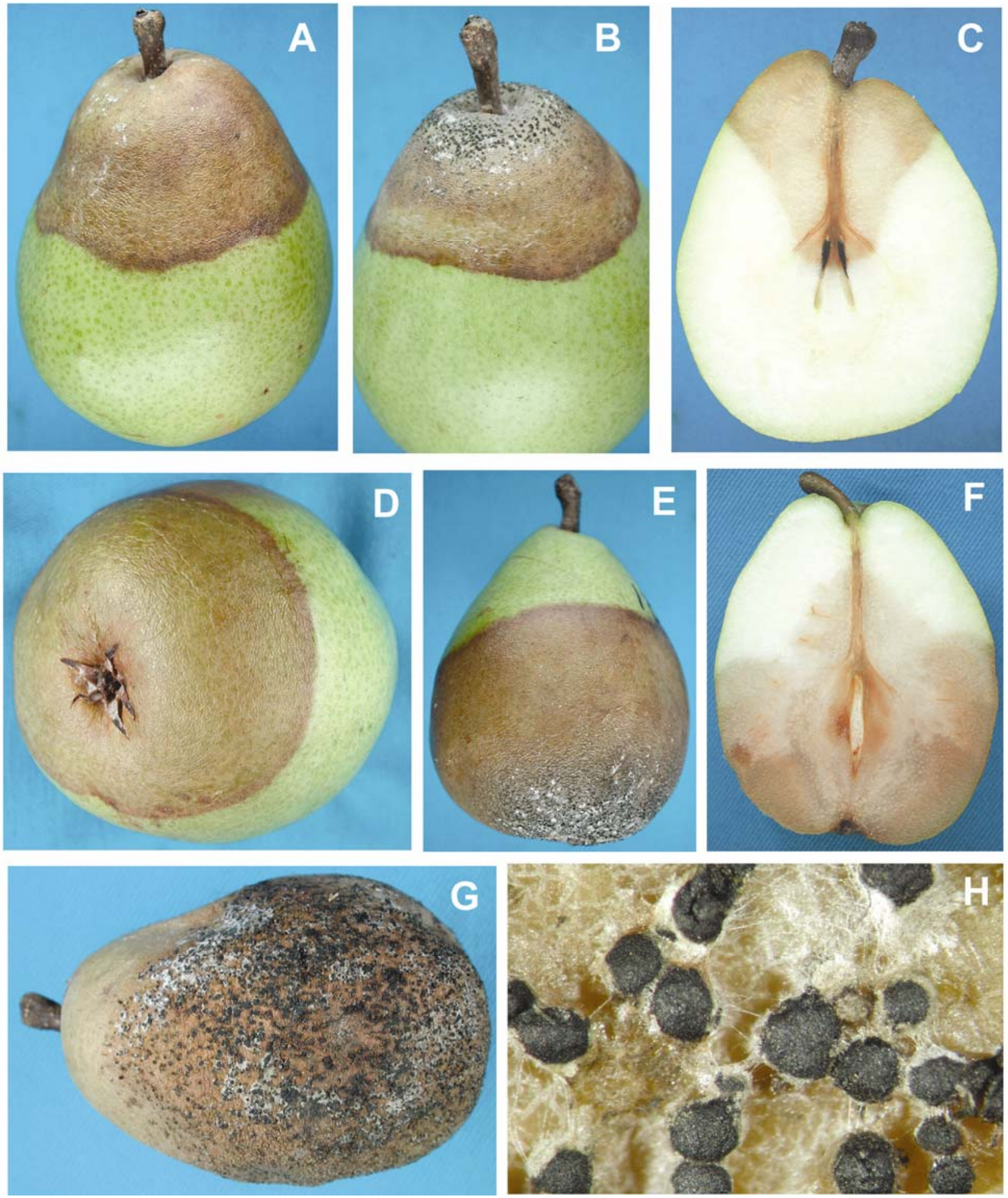

Fig. 1. Symptoms and signs of a fruit rot in d'Anjou pears caused by Sphaeropsis pyriputrescens sp. nov. A and B, stem-end rot; C, internal symptoms of stem-end rot; $\mathbf{D}$ and $\mathbf{E}$, calyx-end rot; $\mathbf{F}$, internal symptoms of calyx-end rot; $\mathbf{G}$, entire fruit decayed with pycnidia formed on the fruit surface; and $\mathbf{H}$, closeup of pycnidia on the fruit surface. 
Pycnidia partly immersed to nearly superficial, subglobose or more or less flattened at the apex, separate to aggregated in small numbers, $0.3-0.7 \mathrm{~mm}$ diameter, thick-walled. Ostioles poroid, inconspicuous. Conidiogenous cells subglobose, 12$16 \mu \mathrm{m}$ long, $8-12 \mu \mathrm{m}$ wide, lining wall of pycnidium, possibly proliferating percurrently; producing conidia holoblastically. Conidia brown, clavate to subglobose to irregular, flattened at secession end, smooth, (11-)14-17(-23) $\times(7-) 8-10(-13)$ $\mu \mathrm{m}$. (Ave. $25=16 \times 10 \mu \mathrm{m}$ ).

Specimen examined. UNITED STATES, WASHINGTON STATE: Wenatchee, Chelan County, on fruit of d'Anjou pear (Pyrus communis L.), Xiao, C. L., 19 March 2002 (HOLOTYPE: WSP 70466; ISOTYPE: WSP 70467); Peshastin, Chelan County, dried culture isolated from a decayed fruit of d'Anjou pear (Pyrus communis L.) collected from a commercial fruit packinghouse, Xiao, C. L., 12 December 2001 (WSP 70468. Living culture ATCC MYA-2947).

Cultural descriptions. Colony morphology of the three isolates of $S$. pyriputrescens was very similar. On PDA, OMA, and PJA at $20^{\circ} \mathrm{C}$, the fungus grew at an average of 21,15 , and $24 \mathrm{~mm}^{-1}$ in $^{-1}$ colony diameter, respectively. On PDA and PJA, the fungus formed a circular colony, with dense, hyaline appressed to aerial mycelia. Two-week-old colonies on PDA were light yellow to yellow. On PJA, colonies were similar to those on PDA but lacked yellow pigmentation. On OMA, the fungus also formed colonies similar to those on PDA and PJA. The reverse of OMA colonies often became light yellow. On OMA, the fungus began forming pycnidia after 7 days under 12 -h light/12-h dark at $20^{\circ} \mathrm{C}$. Pycnidia were initially light gray. After 10 days of incubation, the mature pycnidia in the central area on the plate were gray to black. Yellowish-brown conidia were produced abundantly inside the mature pycnidia, whereas less mature pycnidia near the edge of the plates appeared light gray and contained light-colored immature conidia.

Temperature studies. Temperature responses of the three isolates of S. pyriputrescens were virtually the same. Isolates of Sphaeropsis sp. were able to grow at temperatures from 0 to $25^{\circ} \mathrm{C}$, with little or no growth at $30^{\circ} \mathrm{C}$ and no growth at $35^{\circ} \mathrm{C}$. The optimal growth temperature was between 15 and $20^{\circ} \mathrm{C}$, with mean growth rates of 13 to $16 \mathrm{~mm} \mathrm{day}^{-1}$ in colony diameter. The average growth rates on OMA at 0 and $5^{\circ} \mathrm{C}$ were 2 and $5 \mathrm{~mm} \mathrm{day}{ }^{-1}$ in colony diameter, respectively. Cultures that showed little or no growth at $30^{\circ} \mathrm{C}$ for 10 days recovered and resumed growth after incubation at $20^{\circ} \mathrm{C}$. Cultures of all three isolates that failed to grow after 10 days at $35^{\circ} \mathrm{C}$ did not recover after incubation at $20^{\circ} \mathrm{C}$. This is a low-temperature species. By comparison, the isolate of $S$. malorum grew at temperatures from 5 to $30^{\circ} \mathrm{C}$, with little growth at $35^{\circ} \mathrm{C}$ and no growth at $0^{\circ} \mathrm{C}$. The optimal growth temperature was between 25 and $30^{\circ} \mathrm{C}$, with an average growth rate of $33 \mathrm{~mm} \mathrm{day}^{-1}$ in colony diameter. The growth rate of $S$. malorum on OMA at $5^{\circ} \mathrm{C}$ was $2 \mathrm{~mm}$ day $^{-1}$ in colony diameter.

\section{DISCUSSION}

This is the first report of a new fruit rot in stored d'Anjou pears caused by the new fungal species, Sphaeropsis pyriputrescens. It is unknown how long this disease has been present in Washington State, because to our knowledge, detailed surveys for postharvest diseases in pears have not been conducted in Washington State during the past 60 years. The previous survey of fungi associated with stored pears in Washington State was conducted in the late 1930s (2). English (2) reported 75 distinct fungal species belonging to 22 genera associated with fruit rots in stored pears. No Sphaeropsis spp. were reported in that study. Previously, only the Sphaeropsis anamorph of Botryosphaeria obtusa in the genus Sphaeropsis had been reported as a fruit rotting pathogen in pears and apples $(5,13)$, but it was erroneously called S. malorum (12). S. malorum is the causal agent of black rot of apples and pears, and is of particular importance in the southeastern United States $(1,15)$. The symptoms of black rot may appear in the orchard, and rotted fruit may drop prematurely from the tree. Fruit infected shortly before harvest by $S$. malorum may develop symptoms in storage, depending on storage temperatures, but further development of decay is prevented at storage temperatures near $0^{\circ} \mathrm{C}$ (13). In contrast, symptoms of the new disease we report here developed at storage temperatures between -1 and $0^{\circ} \mathrm{C}$. S. malorum was not able to grow at $0^{\circ} \mathrm{C}$, while $S$. pyriputrescens grew well at $0^{\circ} \mathrm{C}$. This supports our observations that this new disease develops on pears during cold storage and is different from black rot caused by $S$. malorum, which is not able to grow at the pear storage temperatures between -1 and $0^{\circ} \mathrm{C}$.

Based on our survey, this new disease occurred in approximately $46 \%$ of the sampled lots (orchards) but at a relatively low level. The relatively low incidence of this disease might indicate a low level of pathogen inoculum in the orchard. Although we have not found the fungus on trees in the orchard based upon a limited number of samples examined, inoculation with the fungus in the orchard indicated that the fungus has the ability to cause cankers on wound-inoculated twigs (C. L. Xiao, unpublished data). We have also observed that the fungus formed pycnidia on the dead tissue of inoculated twigs in the orchard.
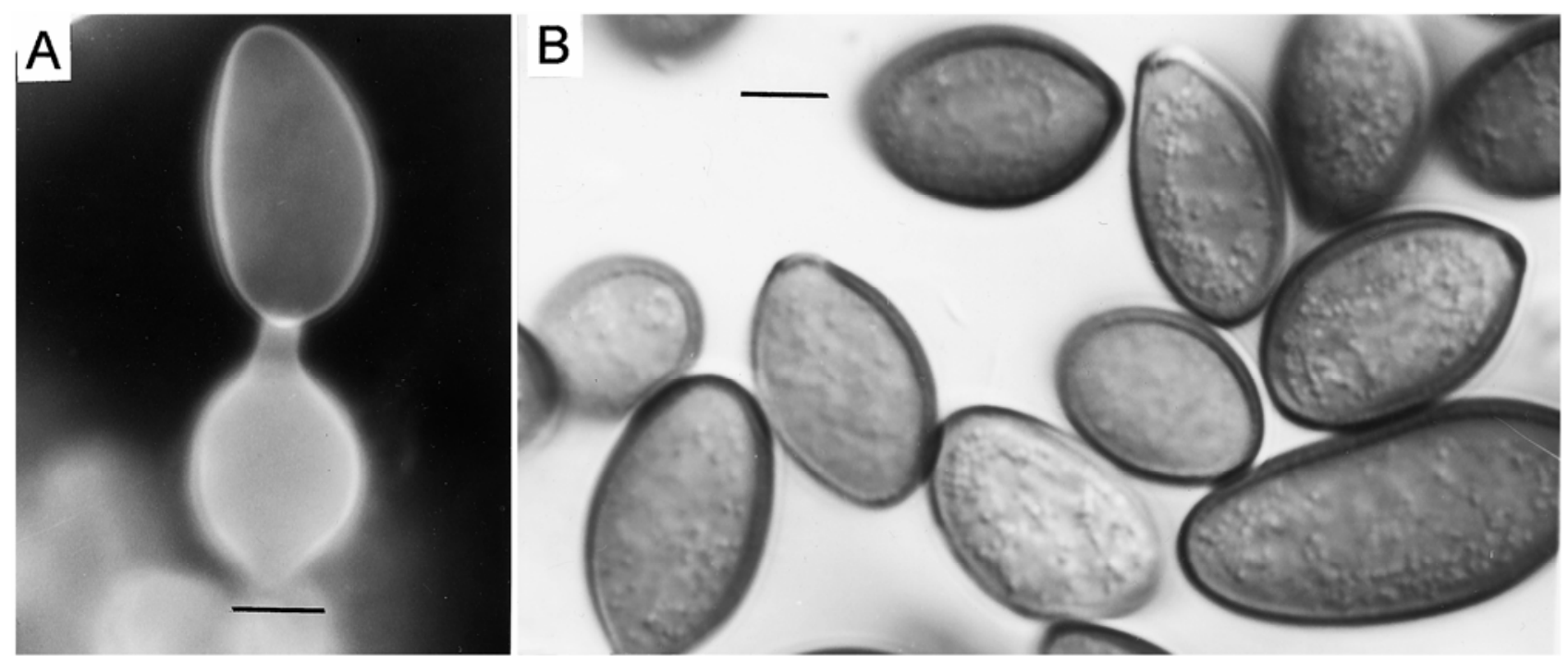

Fig. 2. Sphaeropsis pyriputrescens sp. nov. A, conidiogenous cell bearing conidium, by dark field fluorescence microscopy; B, conidia, the paler ones immature, by differential interference contrast microscopy. Scale bars $=5 \mu \mathrm{m}$. 
Thus, based upon our understanding of the biology of the fungus, we speculate that the fungus is presumably present as pycnidia and/or mycelium in dying or dead bark or twigs on trees in the orchard.

The occurrence of this new disease on pears in field bins during storage indicated that infections of stem and calyx tissues by the fungus take place in the orchard, because fruit are directly stored in the bin without any postharvest drench treatments, thus infections due to contamination of fruit by the fungus during drenching or packing processes can be ruled out. This also indicates that, like black rot of apple caused by $S$. malorum, disease control should focus on management practices in the orchard (15).

Among Sphaeropsis species, only $S$. malorum "Peck" is reported to cause decay of pear fruit $(3,5)$. According to Shoemaker (12), Peck found the conidial state of Botryosphaeria obtusa (Schwein.) Shoemaker, misidentified it, and reported it as Sphaeropsis malorum Berk. Although Peck (7) did not name the fungus, the name has been erroneously ascribed to him (for example, Saccardo [10]). Stevens (14) had previously examined relevant types and considered the coelomycete in question to be anamorphic Physalospora obtusa (Schwein.) Cooke, which Shoemaker (12) instated in Botryosphaeria. Conidia were described by Shoemaker (12) as brown with a finely roughened wall, mostly $22-26 \times 10-12 \mu \mathrm{m}$. Petrak and Sydow (8) had accepted this or a similar fungus (based in part on North American material) as Botryodiplodia malorum (Berk.) Petrak \& H. Sydow, and described conidia as 22-31 $\times 12-15 \mu \mathrm{m}$. Among other Sphaeropsis and putative Sphaeropsis taxa, $S$. rosarum Cooke \& Ellis conidia are reported as $25 \times 10 \mu \mathrm{m}$, whereas those of $S$. endophloea Passerini are reported as 18-20 $\times 10-12 \mu \mathrm{m}$ (11). S. lichenoides Sacc. conidia are reported as $14-18 \times 7-8 \mu \mathrm{m}$, the general size range of $S$. pyriputrescens, but other aspects of its description indicate that these taxa are different (11). We have not examined material of this taxon or of the other taxa discussed above.

We have examined material of $S$. viscosa Cooke \& Ellis from leaves of Pyrus arbutifolia (L.) L.f. (Massachusetts, Nantucket Co., "Plants of Nantucket," no. 90, leg. G. Wyatt, 7/13/1936, det. E. F. Guba [FH]). Conidia are 22-25 $\times 9-12 \mu \mathrm{m}$. No conidiogenous apparatus was seen. Two North American specimens of $S$. mali (West.) Sacc. from Pyrus bark were examined (Canada, London, E. Bartholomew "Fungi Columbiani," no. 2483, J. Dearness, 8/1907 [BPI USO 366800]) and (Kansas, Rooks Co., Ellis and Everhart "North American Fungi," series 2, no. 3550, E. Bartholomew, 10/1896 [BPI USO $366801]$ ). The conidial size range of the former collection is $22-26.5 \times 12-15 \mu \mathrm{m}$, of the latter collection (19-)22-23.5 × 9-9.5 $\mu \mathrm{m}$; conidia of these collections are smooth-walled. A specimen collection of S. mali from Pyrus bark from France (Gallica, E. Cerny [BPI USO 366533]) has minutely roughened conidia 19-26.5 $\times$ 9$12 \mu \mathrm{m}$. Conidia are highly variable in size and shape and probably are not conspecific with the other collections labeled as $S$. mali. Petrak \& Sydow (8) report conidial dimensions of S. mali ([as Haplosporella mali (West.) Petrak) as 17-25 × 9-12.5 $\mu \mathrm{m}$.

Despite the problems associated with Sphaeropsis and allied genera and the great number of extant names, we believe that science is best served by the erection of a new taxon to delineate the fungus described here. This fungus could be a factor in pear cultivation, and information such as its identity and activities must be readily available. The discovery of this new disease and pathogen also indicates that a routine survey of postharvest diseases is periodically necessary, particularly when orchard practices and postharvest fruit handling practices are changed.

\section{ACKNOWLEDGMENTS}

Plant Pathology New Series 0366, Project 0367, College of Agriculture and Home Economics Research Center, Washington State University. We thank M. Adams, R. J. Boal, D. Corey, and J. W.
Sitton for technical assistance; R. G. Roberts for providing isolates of Sphaeropsis malorum; and the curators of the herbarium cited for the loan of specimens. This research was supported in part by the Winter Pear Control Committee.

\section{LITERATURE CITED}

1. Brown, E. A., II., and Britton, K. O. 1986. Botryosphaeria diseases of apple and peach in the southeastern United States. Plant Dis. 70:480-484.

2. English, W. H. 1940. Taxonomic and pathogenicity studies of the fungi which cause decay of pears in Washington. Ph.D. diss. State College of Washington, Pullman.

3. Farr, D. F., Bills, G. F., Chamuris, G. P., and Rossman, A. Y. 1989. Fungi on Plants and Plant Products in the United States. American Phytopathological Society, St. Paul, MN.

4. Holmgren, P. K., Holmgren, N. H., and Barnett, L. C. 1990. Index Herbariorum. Part I: The Herbaria of the World. 8th ed. New York Botanical Garden, Bronx.

5. Jones, A. L., and Aldwinckle, H. S., eds. 1990. Compendium of Apple and Pear Diseases. American Phytopathological Society, St. Paul, MN.

6. Meheriuk, M. 1993. CA storage conditions for apples, pears, and nashi. Pages $819-858$ in: Proc. Int. Controlled Atmosphere Res. Conf., 6th. Cornell University, Ithaca, NY.

7. Peck, C. H. 1880. Report of the botanist. Pages 24-58 in: Annu. Rep. State Museum Natural History, 34th. Albany, NY.

8. Petrak, F., and Sydow, H. 1927. Die Gattungen der Pyrenomyzeten, Sphaeropsideen und Melanconieen. Repertorium specierum novarum regni vegetabilis. Beihefte. Band 42.

9. Rosenberger, D. A. 1990. Postharvest diseases. Pages 53-54 in: Compendium of Apple and Pear Diseases. A. L. Jones and H. S. Aldwinckle, eds. American Phytopathological Society, St. Paul, MN

10. Saccardo, P. A. 1884. Sylloge fungorum omnium hucusque cognitorum. III. Padua, Italy.

11. Saccardo, P. A. 1892. Sylloge fungorum omnium hucusque cognitorum. X. Padua, Italy.

12. Shoemaker, R. A. 1964. Conidial status of some Botryosphaeria species on Vitis and Quercus. Can. J. Bot. 42:1297-1303.

13. Snowdon, A. L. 1992. Post-harvest Diseases and Disorders of Fruits and Vegetables, Vol. 1. General Introduction and Fruits. CRC Press, Boca Raton, FL.

14. Stevens, N. E. 1933. Two apple black rot fungi in the United States. Mycologia 25:536-548.

15. Sutton, T. B. 1990. Black rot. Pages 18-20 in: Compendium of Apple and Pear Diseases. A. L. Jones and H. S. Aldwinckle, eds. American Phytopathological Society, St. Paul, MN. 